\title{
LONG-RUN GROWTH AND
} DEMOGRAPHIC PROSPECTS IN ADVANCED ECONOMIES

Galo Nuño, Cristina Pulido and Ruben Segura-Cayuela

Documentos ocasionales N. 1206

\section{BANEODE ESPANA}

\author{
Eurosistema
}


LONG-RUN GROWTH AND DEMOGRAPHIC PROSPECTS IN ADVANCED

ECONOMIES 


\title{
LONG-RUN GROWTH AND DEMOGRAPHIC PROSPECTS IN
} ADVANCED ECONOMIES

\author{
Galo Nuño (*) \\ EUROPEAN CENTRAL BANK \\ Cristina Pulido \\ BANCO DE ESPAÑA \\ Rubén Segura-Cayuela (*) \\ BANK OF AMERICA MERRIL LYNCH
}

$\left.{ }^{*}\right)$ This paper was written while Galo Nuño and Rubén Segura-Cayuela were affiliated to the Banco de España. The authors would like to thank, for their valuable comments, Enrique Alberola, Ignacio Hernando, Pilar L'Hotellerie-Fallois, Pedro del Río and Javier Vallés, as well as seminar participants at the Joint Informal Workshop for NCBs held in Madrid in March 2012. The opinions expressed by the authors do not necessarily reflect the positions of the European Central Bank, the Banco de España or the Eurosystem. 
The Occasional Paper Series seeks to disseminate work conducted at the Banco de España, in the performance of its functions, that may be of general interest.

The opinions and analyses in the Occasional Paper Series are the responsibility of the authors and, therefore, do not necessarily coincide with those of the Banco de España or the Eurosystem.

The Banco de España disseminates its main reports and most of its publications via the INTERNET at the following website: http://www.bde.es.

Reproduction for educational and non-commercial purposes is permitted provided that the source is acknowledged.

C BANCO DE ESPAÑA, Madrid, 2012

ISSN: 1696-2230 (on line) 


\begin{abstract}
This paper analyses the long-run growth rates of advanced economies, based on demographic factors. To this end, growth is broken down into two components: growth in productivity (GDP per working-age person) and the projected rate of growth of the working-age population. Productivity is assumed to grow in the longrun at a constant rate equal to that of the technology leader, whereas the demographic projections are those of the United Nations. This simple methodology abstracts from other factors normally considered in the literature on long-term growth, such as the convergence process (we focus on advanced economies) and heterogeneity in participation and employment rates. However, the results do not differ much from those obtained using these other approaches (which are richer, but also more speculative), although the growth rates turn out to be somewhat lower in most cases. They indicate a general deceleration of growth in advanced economies in the coming two decades, due to a slowdown in working-age population growth. Japan, Germany, Italy and Spain face the least favourable growth dynamics in our sample, as these countries face reductions in the size of their workforces. By 2050 France and the United Kingdom could have overtaken Germany to become the largest economies in Europe. In the case of Spain (whose working-age population is expected to peak in 2024) the growth rate of GDP will progressively decline to just below $2 \%$ over the following decade.
\end{abstract}

Keywords: Advanced economies, demography, convergence, endogenous growth.

JEL classification: E20, O40, O50. 


\section{Resumen}

Este documento analiza las tasas de crecimiento de largo plazo para una muestra representativa de economías avanzadas, sobre la base de las perspectivas demográficas. Para ello, se descompone el crecimiento del PIB en dos factores: el crecimiento de la productividad (definida como PIB por persona en edad de trabajar) y el crecimiento de la población en edad de trabajar. En particular, se supone una tasa de crecimiento de largo plazo de la productividad constante e igual a la del líder tecnológico, y para la población se toman las proyecciones demográficas de Naciones Unidas. Esta metodología sencilla no tiene en cuenta otros factores utilizados en la literatura del crecimiento de largo plazo, tales como los procesos de convergencia -por lo que este documento se centra exclusivamente en economías avanzadas- o la heterogeneidad en la participación y las tasas de empleo. Sin embargo, los resultados de este trabajo no difieren mucho de otros estudios basados en un conjunto más amplio de supuestos. En todo caso, los resultados apuntan a una disminución generalizada del crecimiento en las economías avanzadas durante las próximas dos décadas, debido a un descenso del crecimiento de la población en edad de trabajar. Japón, Alemania, Italia y España son los países de la muestra analizada que se enfrentan a los escenarios demográficos más adversos, con reducciones de su fuerza laboral. En el caso de la economía española se espera que el crecimiento de la población en edad de trabajar (la cual alcanzaría su máximo en 2024) se ralentice, lo que posiblemente contribuirá, de manera progresiva, a reducir la tasa de crecimiento del PIB a largo plazo (situándose ligeramente por debajo del $2 \%$ en la próxima década). Hacia el año 2050, el tamaño de las economías de Francia y Reino Unido podría haber sobrepasado al de Alemania.

Palabras clave: economías avanzadas, demografía, convergencia, crecimiento endógeno.

Códigos JEL: E20, O40, O50. 


\section{Introduction}

What is the long-run growth rate of advanced economies? The sustained period of growth that most advanced countries experienced in the 2000s came to an end with the economic crisis that began in 2008. Since then, policymakers and analysts alike have focused on how to solve the different challenges posed by the crisis in order to ensure a return to a sustainable growth path for these economies. However, regardless of the importance of the current problems, it is essential to have a clear perspective of the medium and long-run challenges that advanced economies will face in the coming two decades, as an adequate diagnosis is necessary to begin implementing the right measures today.

In particular, as will be made clear in this paper, many advanced economies are entering a new phase of economic development characterised first by a slowdown and then by a decline of their working-age populations. Some countries such as Japan have been coping with this reality for the last two decades, whereas others such as Spain will face it in the coming years. Therefore, advanced economies should be ready to face a future characterised by slower GDP growth rates than in the past.

It may be argued that the main priority of policymakers should be the rate of per capita GDP growth instead of the total GDP growth, as citizens are only concerned about the growth in their own income. This assumption may be true in general terms, but there are several risks associated with low output growth. In the first place, a reduction in the aggregate growth rate has direct effects on the sustainability of public and private debt, which depends crucially on the growth rate of aggregate output. A slowdown in the growth rate, ceteris paribus, would make debt service more difficult by overburdening a stable or decreasing working-age population.

In the second place, a reduction in the working-age population and slower output growth may reinforce each other via migratory flows. Slower growth typically reduces immigration as there are fewer job opportunities available, reducing the size of the workforce and thus the growth potential of the economy. This negative feedback effect may adversely affect the price of assets such as housing, due to a steady reduction in demand. A protracted fall in housing prices may have important consequences in terms of the balance sheets of households and financial institutions.

Finally, policymakers could mistake this structural reduction in growth - which is the consequence of demographic trends - for a temporary fall due to the current business cycle. If policymakers erroneously estimate the output gap to be greater than its actual value, they may implement expansionary policies that could be counterproductive. Although we do not explicitly explore those effects in this paper, they are important since they highlight why the question that we pose - the magnitude of the long-run growth rate - is so relevant to the current design of public policies. 
In order to assess the growth potential of advanced economies, in section 2 we briefly sketch what the historical data and economic theory tell us about the long-run growth potential of the various countries. In particular, it highlights how the long-run growth rate of GDP per working-age person of advanced countries converges with that of the technology leader, the United States. Therefore, the difference among countries in the long-run depends mainly on their demographic trends. The demographic projections for advanced economies are analysed in detail in section 3. ${ }^{1}$ We conclude that Japan, Germany, Italy and Spain are four countries that face more challenging demographic prospects, whereas other countries, such as the United States and the United Kingdom, enjoy a more favourable demographic future.

The main results of this paper are presented in section 4. We show how, on average, advanced economies will lose more than 1 percentage point of annual growth in the decade 2012-2021 compared to 1998-2007. In the period 20122031 , the long-run growth rate is computed to be $1.7 \%$, compared to $2.9 \%$ in the period 1988-2007, due mainly to a change from a positive to a negative trend in the growth rate of the working-age population. The heterogeneity of the demographic projections will affect the relative size of the economies, and by 2050 France and the United Kingdom could have overtaken Germany to become the largest economies in Europe. In the case of Spain (whose working-age population is expected to peak in 2024) the growth rate of GDP will progressively decline to just below $2 \%$ over the following decade.

Section 5 compares our exercise with similar recent exercises and explains the differences in assumptions and results among them. Exercises that incorporate convergence elements provide a somewhat less dramatic picture than ours, but at the cost of introducing a higher degree of judgment and, thus, subjectivity. It also shows how our measure of long-term growth resembles measures of historical potential output growth. Finally, section 6 concludes by summarising the main arguments in the article. 


\section{Economic growth in the long-run}

At the beginning of the $19^{\text {th }}$ century a number of countries, led by the United Kingdom, experienced an increase in the growth rate of its output per working-age person. This reflected the transition from a traditional to a capitalist economy due to the Industrial Revolution. In the $20^{\text {th }}$ century, the United States took up the role of the technology leader from the United Kingdom. Since then, the growth rate of the GDP per working-age person in the United States has fluctuated around a constant value of 1.7 percent. Despite the fluctuations, the trend growth has been quite stable: the logarithm of the GDP per capita in 2000 could have been forecasted with a small error if we had drawn a straight line using data from 1950 to 1965, as shown in figure 1.

\section{Figure 1: Historical evolution of the logarithm GDP}

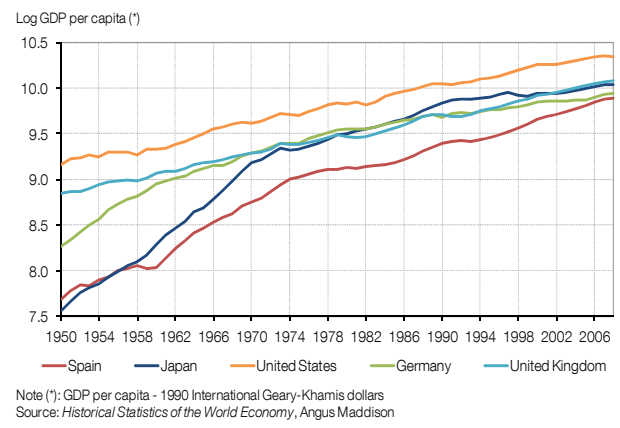

Note ("): GDP per capita- 1990 International Geary-Khamis dollars
Source: Historical Statistics of the World Economy, Angus Maddison

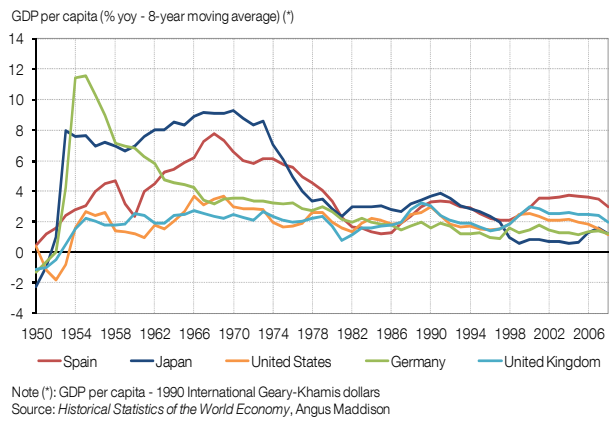

Source: Historical Statisticics of the World Economy, Angus Maddison

This empirical fact was first explained by the neoclassical economic literature such as Solow (1956). Provided that returns to scale in labor and capital were decreasing, the long-run ("steady-state") growth rate of per capita GDP is equal to the growth rate of the so-called total factor productivity (TFP). It means that, as long as the marginal product of building more factories or employing more people in each of the existing factories is decreasing, per capita income growth will depend solely on the growth rate of technology. As the "exogeneity" of the TFP was not quite satisfying as a theory, the "endogenous growth literature" was able to explain the process of technological innovation as the result of the working of researchers and entrepreneurs who produce new technological breakthroughs in order to capture some monopolistic rents. ${ }^{2}$ This literature explained the long-run growth rate of technology as a function of the diverse barriers to entrepreneurship and the productivity of research and development (R\&D) efforts.

What about the growth rate of the rest of the countries in the World? Here a distinction should be made between advanced and developing countries. In the case of advanced countries, their GDP per capita have been converging in the $20^{\text {th }}$ century to parallel growth paths (linear in logarithms), as shown in figure 1. This convergence was not a homogeneous process. In the case of some countries, such as Germany or France, it began in the $19^{\text {th }}$ century and, despite being interrupted 
(and temporarily reverted) by the two World Wars, it continued throughout the $20^{\text {th }}$ century until their growth paths were parallel to that of the U.S., that is, their mean growth rates were equal to 1.7 percent. In other countries, such as Japan or Spain, the process was accelerated in the post-war period and by the end of the century they seemed to have converged to parallel growth paths.

The Solow model predicted this kind of economic convergence of countries. As a backward country begins to accumulate capital, its growth rate increases above that of the technological leader, however this growth effect progressively fades away as its per-capita capital gets closer to that of the leader. The problem was that the Solow model predicted not only a convergence in growth rates, but also a convergence in the levels of per-capital income, a feature not observed in the data where there are permanent income-level gaps between advanced countries. The new generation of endogenous growth models, such as the one by Howitt (2000), was able to explain also this fact as a result of the barriers to technology adoption between follower countries and the leader. In particular, the theory explained how, in the first stages of industrialization, a country is able to grow faster than the leader due to capital accumulation and technology adoption. After a certain time, these effects fade away and the country grows at the same rate than the technological leader (in terms of GDP per working-age population) despite the existence of a permanent gap in the level of income, which is the result of the barriers to technology adoption. In this model, structural reforms are able to reduce this gap in levels but cannot permanently increase the growth rate in the long-run. ${ }^{3}$

The problem is more complex if we consider developing countries (i.e. those countries whose productivity growth rates have not converged to those of the technological leader). As discussed in Howitt and Mayer-Foulkes (2005), there seems to be no "catch-up" process in the poorest countries in the world. Therefore, developing countries could in principle be subdivided in two groups: those that are actually in the convergence process and those that are not. Of course, some countries have moved from one group to the other in the last century (and sometimes they have switched sides several times) producing the so-called growth "miracles" and "disasters". According to Howitt and Mayer-Foulkes, even countries that are in a convergence path may converge to a growth rate below that of the advanced countries due to barriers to technology adaptation. The bottom line is that assessing the future growth rate of emerging countries is a more complex task than in advanced ones.

Returning to the problem of assessing the growth potential of advanced countries, the previous discussion should have clarified that, in the long-run, it is very close to that of the technological leader. That is, over protracted periods of time, countries that have already converged to its long-run ("steady-state") path should have growth rates of their GDP per working age population close to 1.7 percent. ${ }^{4}$ To verify this, Figure 2 displays the histogram of annual growth rates of GDP per working-age population -defined as "productivity"- for a wide sample of 16

3. However, structural reforms do increase the growth rate in the transition path from one income level to a higher one. 4. It should be noticed that so far we have indistinctly used the notions of GDP per capita or per working-age population. These two values have been similar in the past for most countries, but they will differ in the future as population age and decline, which is one of the central points of this paper. Therefore, from now on we always refer to working-age population, which is the correct variable to analyze. 
advanced economies 5 . The variance of the distribution is characterized by the volatility of the business cycles, whereas the mean is the average growth rate for this sample which is 1.7 percent. Therefore, economic theory predictions seem to be validated by the data of the last two decades, and the "productivity" of advanced economies can be confidently forecasted to grow, on average, at 1.7 percent.

Figure 2: Historical distribution of GDP per working-age population across a sample of 16 advanced countries

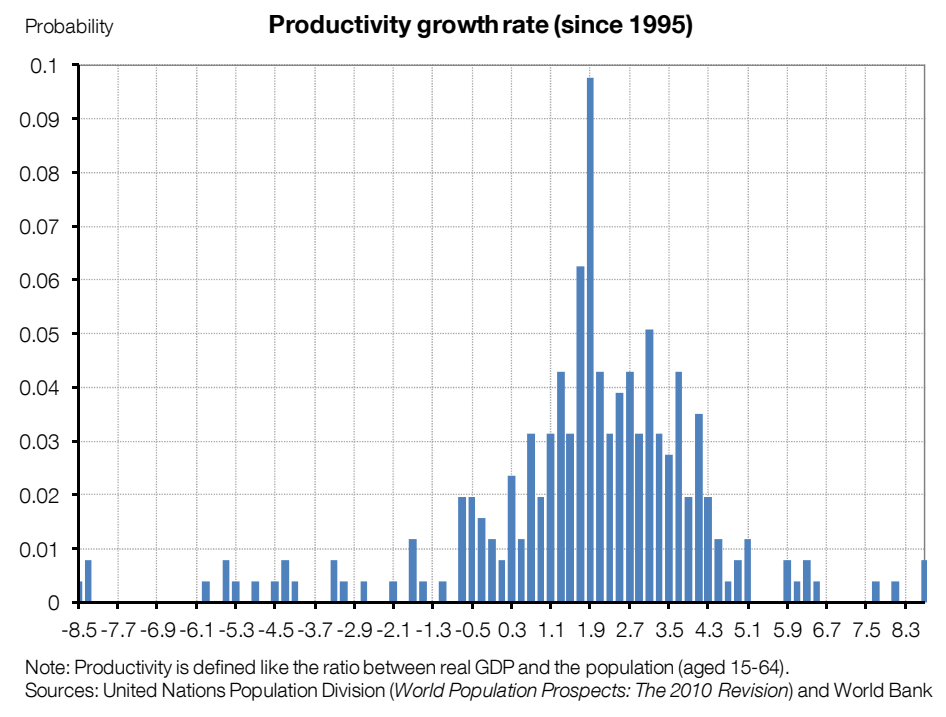

A constant productivity growth in the long run does not imply a constant GDP growth rate. As we discuss in the next section, the demographic projections for advanced economies yield a heterogeneous picture for the decades to come. This variability in the growth rate of the working-age populations will have a deep impact on GDP projections.

5. The sample of countries chosen in this paper is composed by Australia, Canada, Finland, France, Germany, Iceland, Ireland, Italy, Japan, Netherland, New Zealand, Norway, Spain, Sweden, United Kingdom and United States. These countries have been selected as a representative sample of advanced OECD economies. 


\section{Demographic projections}

In this section we carefully explain the source of demographic information and how projections are made. Projections about population should in principle be more reliable than about other issues, as they imply high levels of inertia. For example, most of the working-age population in 2025 has already been born. ${ }^{6}$ Notwithstanding, the reassessment of migratory flows can sometimes make the demographic assessment more uncertain, so the projection should be taken with a grain of salt ${ }^{7}$, as explained below.

The data for demographic projections has been obtained from the World Population Prospects: The 2010 Revision, developed by the United Nations Department of Economic and Social Affairs/Population Division (henceforth UNPD), the main reference for demographic projections in social sciences. From this data set we obtain for each country in our sample yearly data on the total population aged 15-64 for the period 1950-2100.

It is important to distinguish the differences in methodology between official population estimates and projections, since they determine the uncertainty surrounding our exercises. The official population estimates (period 1950-2010) are obtained by incorporating all new information regarding demographic dynamism of each country or geographic area in the past, while population projections (period 2010-2100) are obtained by formulating some detailed assumptions about the future paths of fertility, mortality and international migration.

Regarding projections, the starting point is the estimated population by the end of June 2010. Whenever this estimate is not available, the 2010 estimate is derived from the last population data available (obtained usually from a population census or a population register), which is projected to 2010 using all available information about the trends of fertility, mortality and international migration from that date to 1 July 2010. When data for the last 5 or 10 years are not available, projections are done based on the most recent available data in order to get the estimated demographic trends. In order to project population to 2100 the data set contains eight different projection variants which correspond to different assumptions regarding fertility, mortality and international migration (see Table 1 for a description of these different scenarios).

6. Working-age population is typically defined as the number of people from 15 to 64 years old.

7. Note that migrations tend to be procyclical, so that current projections made at a certain time period can be influenced by the cyclical situation, introducing uncertainty or volatility in the recurrent forecasts. For instance, in periods of intense expansion, where immigration is high, the recent trends of migration could be extrapolated into the future, leading to an overestimation of future flows. 
Table 1: Projection variants in terms of assumptions for fertility, mortality and international migration

\begin{tabular}{|c|c|c|c|}
\hline \multicolumn{4}{|c|}{ Projection variants in terms of assumptions for fertility, mortality and international migration } \\
\hline Projection variant & Fertility & Mortality & $\begin{array}{c}\text { International } \\
\text { Migration }\end{array}$ \\
\hline Low fertility & Low & Normal & Normal \\
\hline Medium fertility & Medium & Normal & Normal \\
\hline High fertility & High & Normal & Normal \\
\hline Constant-fertility & Constant as of $2005-2010$ & Normal & Normal \\
\hline Instant-replacement-fertility & Instant-replacement as of 2010-2015 & Normal & Normal \\
\hline Constant-mortality & Medium & Constant as of 2005-2010 & Normal \\
\hline No change & Constant as of $2005-2010$ & Constant as of 2005-2010 & Normal \\
\hline Zero-migration & Medium & Normal & Zero as of 2010-15 \\
\hline
\end{tabular}

In this paper, in order to remain neutral regarding the future evolution of these three variables, we use the medium fertility variant. This scenario assumes medium-fertility, and normal mortality and international migration. The medium fertility assumption is based on the assumption that the evolution of fertility includes three broad phases: (i) a high-fertility pre-transition phase (phase I); (ii) the fertility transition itself (phase II) and (iii) a low-fertility post-transition phase (phase III, during which fertility probably fluctuates close to replacement level, or converges towards it). ${ }^{8}$

The normal-mortality assumption is based on the models for life expectancy changes developed by UNPD, taking into account recent trends in life expectancy by gender, and allowing for the impact of pandemics such as the HIV.

Finally, regarding the normal-migration assumption, short-run projections are based on recent experience and on political views on the subject at the country level. These numbers are then kept constant over the next decades. After midcentury it is assumed to gradually decline to zero until 2100 .

Table 2 summarizes for our sample of countries the UNPD projections for working-age population. The information displayed includes the year in which the maximum level of working-age population is achieved in each country, the ratio between working-age population in 2027 and working-age population today, and the ratio between working-age population in 2027 and its maximum level. It is important to distinguish between two set of countries. Firstly, those countries with an increasing working-age population over the whole or most of the period of analysis. These countries are Australia, Iceland, Ireland, New Zealand, Norway, Sweden, and the US (in all these countries the maximum working-age population is not reached before 2100), Canada (reaching the maximum working-age population

8. Other assumptions about the future trends of fertility formulated by the UNPD are the high-fertility assumption, where fertility remains at a level 0.5 children above the fertility in the medium variant over most of the projection period; the lowfertility assumption, where fertility remains at a level 0.5 children below the fertility in the medium variant over most of the projection period; the constant-fertility assumption, where, for each country, fertility remains constant at the estimated level for the period 2005-2010 and finally, the instant-replacement assumption, where fertility is set for each country to the necessary level to ensure a net reproduction rate of 1 from the period 2010-2015. For more detailed information about the assumptions formulated by the UNPD regarding the future paths of fertility, mortality and international migration see United Nations, Department of Economic and Social Affairs, Population Division (2011b). World Population Prospects: The 2010 Revision, Volume l: Comprehensive Tables. 
in 2078), France (reaching the maximum working-age population in 2099), and the UK (reaching the maximum working-age population in 2048). A second set of countries have a less favorable demographic evolution. Among them, some have already reached peak working-age population levels: Finland, Germany, Italy, Japan and the Netherlands. Another country, Spain, will reach this peak in 2024, after 12 years of very slow growth (notice that working age population in 2027 will be very similar to that of 2012, and at the same time, there is also little difference between working age population in 2027 and its peak in 2024).

Table 2: Demographic projections for the sample of countries

\begin{tabular}{|c|c|c|c|}
\hline $\begin{array}{c}\text { Demographic } \\
\text { projections }\end{array}$ & $\begin{array}{c}\text { Maximum working- } \\
\text { age population } \\
\text { year }\end{array}$ & \begin{tabular}{c|} 
Working-age \\
population 2027/ \\
Working-age \\
population 2012 \\
\end{tabular} & \begin{tabular}{|c|} 
Working-age \\
population 2027/ \\
Maximum working- \\
age population \\
\end{tabular} \\
\hline Australia & 2100 & 110 & 85 \\
\hline Canada & 2078 & 101 & 90 \\
\hline Finland & 2010 & 93 & 92 \\
\hline France & 2099 & 100 & 92 \\
\hline Germany & 1997 & 89 & 86 \\
\hline Iceland & 2100 & 108 & 90 \\
\hline Ireland & 2100 & 110 & 84 \\
\hline Italy & 2010 & 95 & 95 \\
\hline Japan & 1995 & 89 & 81 \\
\hline Netherlands & 2010 & 95 & 95 \\
\hline New Zealand & 2100 & 107 & 89 \\
\hline Norway & 2100 & 103 & 87 \\
\hline Spain & 2024 & 101 & 100 \\
\hline Sweden & 2100 & 101 & 95 \\
\hline United Kingdom & 2047 & 103 & 98 \\
\hline United States & 2100 & 104 & 81 \\
\hline
\end{tabular}

This heterogeneity translates into a very different situation in a 15 year period. In 2027 working-age population are expected to decrease in Germany and Japan (11 percent), Finland (7 percent), and Italy and the Netherlands (5 percent). On the other hand, the largest increases in working-age population would be in Australia and Ireland (10 percent), Iceland (8 percent), New Zealand (7 percent), and the U.S. (4 percent). In other words, there will be a difference of 21 percentage points on the relative working age population of the countries with the most and least favorable demographic evolution in 2027 relative to today, something that, as we will see, will condition dramatically their relative economic performance.

It is also important to understand the speed at which working-age population will either converge or diverge to/from peak levels. Figure 3 tries to capture this dynamic behavior by plotting the evolution of working-age population 15 years before and after peak levels. All countries are lined up at peak levels and the cross mark in each line represents the current year (2012). Working-age populations are normalized to be 100 at peak levels and the legend shows the year where peak working-age population is reached. The figure reflects the evolution of working-age population for the four countries that face some of the most challenging demographic projections, Germany, Italy, Japan, and Spain. As it is shown, the four countries follow similar demographic trends, with Japan being the pioneer country in the demographic transition. 
Figure 3: Dynamic trend of the population age 15-64 (normalized to 100 the year of the maximum)

\section{Demographic projections}

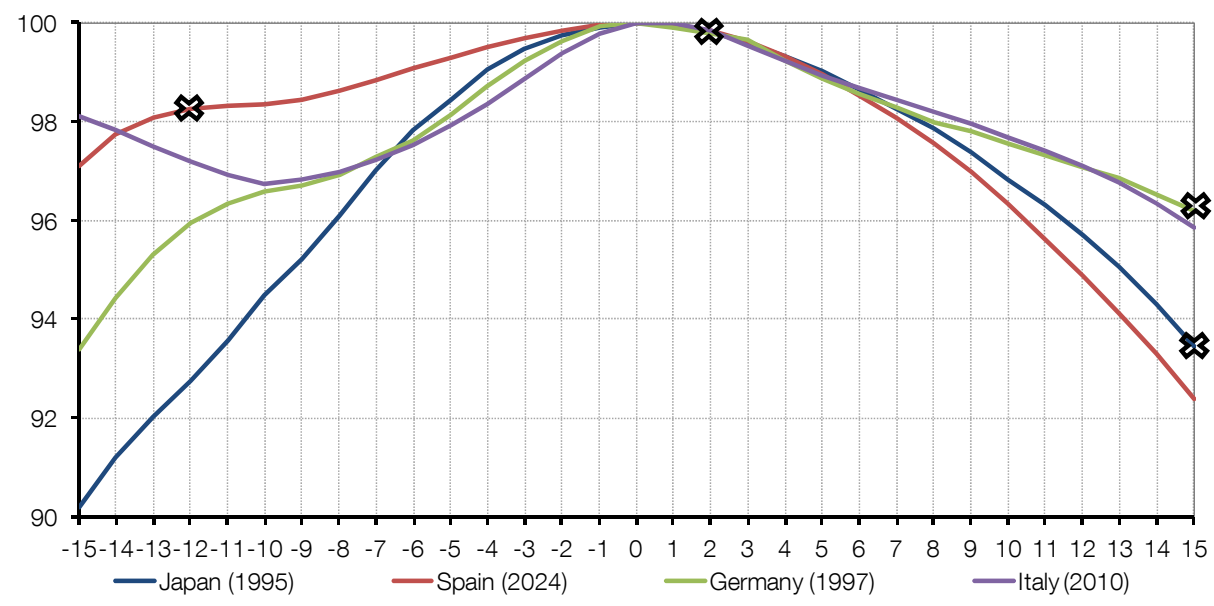

Note: For each country, year in brackets is the maximum working-age population year. The symbol $\mathrm{X}$ marks the year 2012.

Source: United Nations Population Division (World Population Prospects: The 2010 Revision)

An important message is that, although Spain still has 12 years of slightly favorable demographics, once the maximum level of working-age population is reached in 2024 the slope will be much steeper. In other words, working-age population in Spain after 2024 will decrease at rates similar to those experienced by Japan after 1995, rates much faster than those of Germany after 1997 or Italy currently. Again, this ingredient will be important to understand the messages contained in the next section. 


\section{Growth projections}

In this section we integrate the insights from the previous two in order to construct GDP growth forecasts for our sample of advanced economies. These growth forecasts are constructed by combining the demographic projections of United Nations for the working-age population (15-64) with a productivity trend based on a constant growth rate of 1.7 percent:

$$
\Delta \log \left(y_{t}\right) \approx \Delta \log \left(l_{t}\right)+\Delta \log \left(x_{t}\right)=0.017+\Delta \log \left(l_{t}\right)
$$

where $\Delta \log \left(y_{t}\right)$ is the growth rate of GDP, $\Delta \log \left(l_{t}\right)$ is the growth rate of workingage population and $\Delta \log \left(x_{t}\right)$ is the growth rate of "productivity" defined as $x_{t} \equiv \frac{y_{t}}{l_{t}}$.

Table 3 displays the results. ${ }^{9}$ We group the historical data in four groupedcolumns: the first three include the three decades to 1978 to 2007 and the fourth one the crisis period 2008-2011. We provide the mean growth rates of working-age population and GDP observed in the data as well as a counterfactual "long-term" GDP growth defined as the GDP growth in the case of a constant growth rate of productivity of 1.7 percent. The last two columns provide information about our forecast of this "long-term" GDP. The last row displays the simple average across countries, not weighted by GDP or population.

Table 3: Observed and long-run GDP

\begin{tabular}{|c|c|c|c|c|c|c|c|c|c|c|c|c|c|c|c|c|}
\hline \multirow{2}{*}{ Growth rate $(\%)$} & \multicolumn{3}{|c|}{ 1978-1987 } & \multicolumn{3}{|c|}{ 1988-1997 } & \multicolumn{3}{|c|}{ 1998-2007 } & \multicolumn{3}{|c|}{ 2008-2011 } & \multicolumn{2}{|c|}{ 2012-2021 } & \multicolumn{2}{|c|}{ 2022-2031 } \\
\hline & $\begin{array}{l}\text { Working-age } \\
\text { population }\end{array}$ & $\begin{array}{c}\text { Observed } \\
\text { GDP }\end{array}$ & $\begin{array}{c}\text { Long-term } \\
\text { GDP } \\
\end{array}$ & \begin{tabular}{|l} 
Working-age \\
population
\end{tabular} & $\begin{array}{c}\text { Observed } \\
\text { GDP }\end{array}$ & \begin{tabular}{|c|} 
Long-term \\
GDP
\end{tabular} & $\begin{array}{l}\text { Working-age } \\
\text { population }\end{array}$ & $\begin{array}{c}\text { etobserved } \\
\text { GDP }\end{array}$ & \begin{tabular}{|c|} 
Long-term \\
GDP
\end{tabular} & \begin{tabular}{|c|}
$\begin{array}{l}\text { Working-age } \\
\text { population }\end{array}$ \\
\end{tabular} & $\begin{array}{c}\text { Observed } \\
\text { GDP }\end{array}$ & $\begin{array}{c}\text { Long-term } \\
\text { GDP }\end{array}$ & \begin{tabular}{|c|}
$\begin{array}{l}\text { Working-age } \\
\text { population }\end{array}$ \\
\end{tabular} & $\begin{array}{c}\text { Long-term } \\
\text { GDP }\end{array}$ & \begin{tabular}{|c|}
$\begin{array}{l}\text { Working-age } \\
\text { population }\end{array}$ \\
\end{tabular} & $\begin{array}{c}\text { Long-term } \\
\text { GDP }\end{array}$ \\
\hline Australia & 1.7 & 2.9 & 3.5 & 1.3 & 3.3 & 3.0 & 1.5 & 3.6 & \begin{tabular}{|l|} 
\\
\end{tabular} & 1.6 & 2.8 & 3.3 & 0.7 & 2.4 & 0.6 & 2.3 \\
\hline Canada & 1.4 & 3.1 & 3.2 & 1.1 & 2.2 & 2.8 & 1.3 & 3.3 & 3.0 & 0.9 & 0.9 & 2.6 & 0.2 & 1.9 & 0.0 & 1.7 \\
\hline Finland & 0.5 & 3.5 & 2.2 & 0.2 & 1.8 & 1.9 & 0.3 & 3.7 & 2.0 & 0.1 & -0.7 & 1.8 & -0.6 & 1.1 & -0.3 & 1.4 \\
\hline France & 1.0 & 2.1 & 2.7 & 0.3 & 2.1 & 2.0 & 0.6 & 2.3 & 2.3 & 0.3 & 0.1 & 2.0 & 0.0 & 1.7 & 0.0 & 1.7 \\
\hline Germany & 0.7 & 1.9 & 2.4 & 0.3 & 2.7 & 2.1 & -0.2 & 1.6 & 1.5 & -0.3 & 0.3 & 1.4 & -0.6 & 1.1 & -1.2 & 0.5 \\
\hline |celand & 1.4 & 4.3 & 3.2 & 1.1 & 1.2 & 2.8 & 1.5 & 4.7 & 3.2 & 1.6 & -1.5 & 3.4 & 0.6 & 2.3 & 0.4 & 2.1 \\
\hline |reland & 1.1 & 3.0 & 2.8 & 1.2 & 6.2 & 2.9 & 2.0 & 6.7 & 3.7 & 0.8 & -2.5 & 2.5 & 0.6 & 2.3 & 0.7 & 2.4 \\
\hline taly & 0.9 & 2.7 & 2.6 & 0.0 & 1.9 & 1.7 & 0.1 & 1.5 & 1.8 & 0.3 & -0.9 & 2.0 & -0.3 & 1.4 & -0.6 & 1.1 \\
\hline Japan & 0.9 & 4.2 & 2.6 & 0.4 & 2.9 & 2.1 & -0.4 & 1.2 & 1.3 & -0.8 & -0.4 & 0.8 & -0.9 & 0.8 & -0.7 & 1.0 \\
\hline Netherlands & 1.2 & 1.8 & 2.9 & 0.6 & 3.1 & 2.3 & 0.4 & 2.6 & 2.1 & 0.1 & 0.3 & 1.8 & -0.2 & 1.5 & -0.6 & 1.1 \\
\hline New Zealand & 1.2 & 2.0 & 2.9 & 1.3 & 2.1 & 3.0 & 1.4 & 3.3 & 3.1 & 0.9 & 1.2 & 2.7 & 0.5 & 2.2 & 0.3 & 2.0 \\
\hline Norway & 0.6 & 3.5 & 2.4 & 0.5 & 3.2 & 2.3 & 0.9 & 2.4 & 2.6 & 1.2 & 0.5 & 2.9 & 0.2 & 1.9 & 0.2 & 1.9 \\
\hline Spain & 1.1 & 2.0 & 2.8 & 0.7 & 2.8 & 2.4 & 1.2 & 3.8 & 3.0 & 0.7 & -0.2 & 2.4 & 0.2 & 1.9 & -0.2 & 1.5 \\
\hline Sweden & 0.3 & 2.3 & 2.0 & 0.4 & 1.4 & 2.1 & 0.6 & 3.4 & 2.3 & 0.5 & 0.3 & 2.3 & 0.0 & 1.7 & 0.2 & 1.9 \\
\hline United Kingdom & 0.5 & 2.3 & 2.2 & 0.1 & 2.3 & 1.9 & 0.7 & 2.9 & 2.4 & 0.5 & -0.4 & 2.2 & 0.2 & 1.9 & 0.1 & 1.8 \\
\hline United States & 1.1 & 3.1 & 2.8 & 1.0 & 3.0 & 2.7 & 1.3 & 3.0 & 3.0 & 0.7 & 0.6 & 2.4 & 0.4 & 2.1 & 0.2 & 1.9 \\
\hline Average & 1.0 & 2.8 & 2.7 & 0.7 & 2.6 & 2.4 & 0.8 & 3.1 & 2.5 & 0.6 & 0.0 & 2.3 & 0.1 & 1.8 & -0.1 & 1.7 \\
\hline
\end{tabular}

Two results should be highlighted. The first one is the growth deceleration to be expected in the coming decades on average. In the last three decades prior to the crisis (1978-2007), the average growth rate of GDP was of 2.9 percent, slightly above the long-run one of 2.5 percent. This growth was the result of a robust population growth of 0.8 percent plus the productivity growth (observed 2.1, potential 1.7). In the two decades to come, these population growth is expected to halt (average 0 percent) thus inducing a growth rate of GDP of 1.7 percent. This implies that policymakers in advanced economies should be ready to face a growth

9. Historical GDP data comes from the World Bank WDI database, at constant prices. 
loss of more than 1 percent from the pre-crisis due solely to demographic considerations.

The second one is the heterogeneity in the deceleration. The countries more affected by the demographic slowdown are Finland, Germany, Japan, Italy, the Netherlands and Spain. In these countries the average growth rate will be 1.2 percent, half the 2.4 percent rate of the decade 1998-2007. In contrast, the less affected countries are Australia, Iceland, Ireland, New Zealand, the United Kingdom and the United States. In these countries growth is expected to be 2.2 percent, also below the 4.0 percent of the pre-crisis decade.

Figure 4 displays the annual comparison between observed and long-run GDP growth (both historical and projected) for a subsample of countries. We observe how, in general, long-run GDP tracks the average value of the data in a similar way as statistical devices, such as moving average or low-pass filters, would do.

Figure 4: Comparison between observed and long-run GDP for a subsample of countries

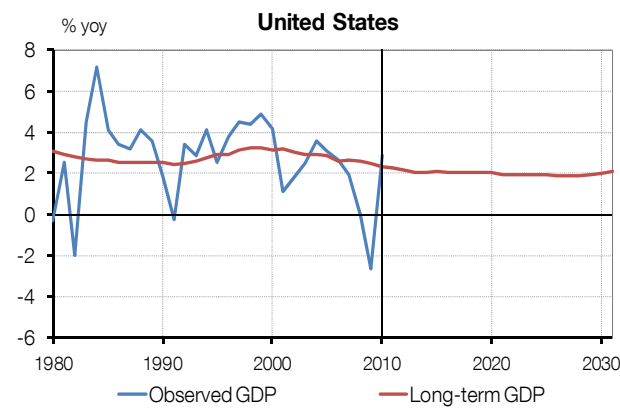

Sources: United Nations Population Division (World Population Prospects: The 2010 Revision) and World Bank.

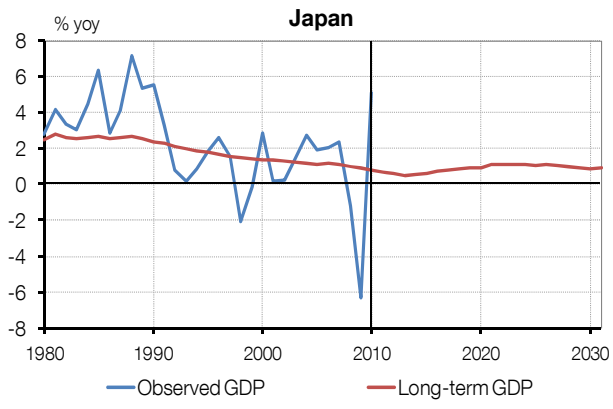

Sources: United Nations Population Division (World Population Prospects: The 2010 Revision) and World Bank.

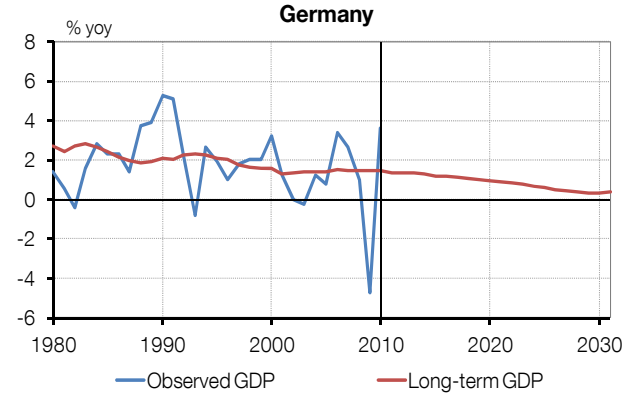

Sources: United Nations Population Division (World Population Prospects: The 2010 Revision) and World Bank.

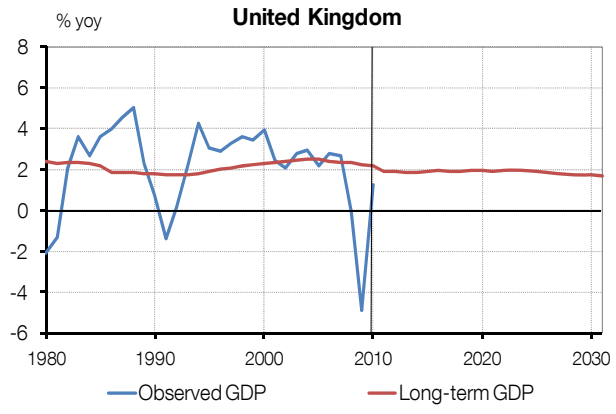

Sources: United Nations Population Division (World Population Prospects: The 2010 Revision) and World Bank.

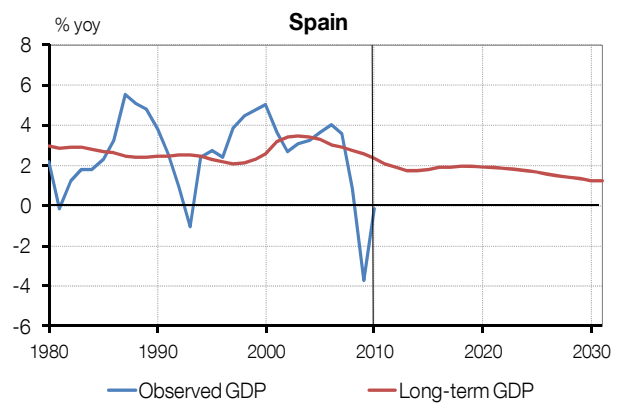

Sources: United Nations Population Division (World Population Prospects: The 2010 Revision) and World Bank.

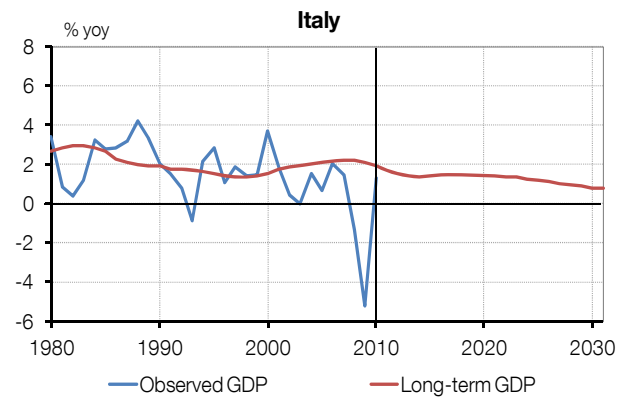

Sources: United Nations Population Division (World Population Prospects: The 2010 Revision) and World Bank. 
In the case of the United States and the United Kingdom, we observe how the long-run GDP growth is expected to slightly decline in the coming decade, but it will be close to 2 percent, still above the productivity rate. In the case of Japan, which is of particular interest as it was the first country in the world to experience the demographic shock, the long-run growth rate has been falling since the early 1990s and it was 1.3 percent in the pre-crisis decade, close to the observed 1.2 percent. In the coming two decades this rate will continue falling until a minimum of 0.8 , to slightly recover afterwards. A similar picture emerges in the case of Germany, where the long-run rate was 1.5 in the pre-crisis and will continue falling until 0.5 percent. Italy, despite the disappointing evolution of its observed GDP before the crisis compared to the long-run trend, is expected to decelerate until a growth of 1.1 percent in the decade 2022-2031. In the case of Spain, the robust pre-crisis growth was fuelled by a sustained growth in its working-age population (1.2 percent) due to the immigration surge in the 2000s plus a growth of productivity of 2.5 percent, well above the 1.7, helped by a convergence process to the technology frontier-and, as we know by large increase in private debt. It should be remarked again that our notion of productivity (i.e. GDP per working person) includes not only TFP but also capital per capita, and improvements in labor participation and employment. Looking at the future, the decade 2012-2021 yields an expected grow rate of 1.9 percent, due to the reduced population growth of 0.2. Shortly after (2024) the projected working population peak is reached, reducing further long-run growth rates, to 1.5 percent in the period 2022 to 2031.

Finally, Table 4 displays the projected size (relative to the US economy) of the largest 9 advanced countries in 2012, 2052 and 2100. The projection is taken assuming that from 2012 onwards countries grow at an average rate equal to their long-run rate. Two features should be remarked. The first is the reduction of the size of the countries compared to the United States. For example, the Japanese economy, which represents almost 30 percent of the U.S. economy nowadays, is forecasted to be less than 17 percent in 2052. The second is the decline of Germany, Italy and Spain, three of the countries with more adverse demographic scenarios. In particular, Germany is forecasted to lose its dominant position as the largest economy in Europe, being overtaken by both France and the United Kingdom. Italy and Spain will both be smaller than Canada in 2052.

Table 4: Relative size of the nine largest (today-) advanced economies

\begin{tabular}{|l|r|}
\hline \multicolumn{2}{|c|}{2012} \\
\hline \multicolumn{1}{|c|}{ Countries } & Long-term GDP \\
\hline United States & 100.0 \\
\hline Japan & 28.2 \\
\hline Germany & 20.2 \\
\hline United Kingdom & 15.5 \\
\hline France & 14.7 \\
\hline Italy & 12.4 \\
\hline Spain & 9.7 \\
\hline Canada & 9.2 \\
\hline Australia & 6.0 \\
\hline
\end{tabular}

\begin{tabular}{|l|r|}
\hline \multicolumn{2}{|c|}{2052} \\
\hline \multicolumn{1}{|c|}{ Countries } & Long-term GDP \\
\hline United States & 100.0 \\
\hline Japan & 16.8 \\
\hline United Kingdom & 13.9 \\
\hline France & 13.0 \\
\hline Germany & 13.0 \\
\hline Canada & 8.5 \\
\hline Italy & 8.4 \\
\hline Spain & 7.2 \\
\hline Australia & 6.3 \\
\hline
\end{tabular}

\begin{tabular}{|l|r|}
\hline \multicolumn{2}{|c|}{2100} \\
\hline \multicolumn{1}{|c|}{ Countries } & Long-term GDP \\
\hline United States & 100.0 \\
\hline Japan & 13.3 \\
\hline France & 12.4 \\
\hline United Kingdom & 12.2 \\
\hline Germany & 11.2 \\
\hline Canada & 7.9 \\
\hline Italy & 7.3 \\
\hline Australia & 6.0 \\
\hline Spain & 5.8 \\
\hline
\end{tabular}

Note: GDP, PPP (constant 2005 international \$) of World Bank is used for this exercise.

Sources: United Nations Population Division (World Population Prospects: The 2010 Revision) and World Bank 


\section{Comparison with other analysis}

To understand the relevance of our results it is important to compare them with those of recent studies addressing similar issues. A first set of papers allow for some convergence in variables such as human and physical capital stocks among these countries, while at the same time taking into account future demographics. It is important to highlight that our exercise does not consider further convergence in the long run, which potentially can generate important differences in the results, as we will show below. Table 5 summarizes the results for all this exercises, including ours. It displays the average growth rate for the period 2030 and 2050.

Table 5: Comparison with other studies

\begin{tabular}{|l|c|c|c|c|c|}
\hline \multirow{2}{*}{ Growth rate (\%) } & \multicolumn{5}{|c|}{ 2030- 2050 } \\
\cline { 2 - 6 } & $\begin{array}{c}\text { Potential GDP } \\
\text { Duval and de la } \\
\text { Maisonneuve (2010) }\end{array}$ & Potential GDP OECD & $\begin{array}{c}\text { Potential GDP } \\
\text { Merola and Sutherland } \\
\text { (2012) }\end{array}$ & Potential GDP HSBC & Long-term GDP \\
\hline Australia & 2.0 & 2.0 & 2.1 & 2.6 & 2.1 \\
\hline Canada & 2.0 & 2.2 & 2.0 & 2.6 & 2.0 \\
\hline Finland & 1.7 & 1.7 & 1.6 & 1.9 & 1.6 \\
\hline France & 2.0 & 1.6 & 1.6 & 1.9 & 1.8 \\
\hline Germany & 1.3 & 1.0 & 0.8 & 1.6 & 1.0 \\
\hline Ireland & 2.4 & 2.2 & 1.8 & 2.1 & 1.9 \\
\hline Italy & 1.5 & 1.5 & 0.8 & 1.8 & 0.9 \\
\hline Japan & 0.9 & 1.4 & 0.6 & 0.7 & 0.6 \\
\hline Netherlands & 1.7 & 1.6 & 1.5 & 1.9 & 1.4 \\
\hline Norway & 1.7 & 2.0 & $n .2$. & 1.8 & 1.9 \\
\hline Spain & 1.6 & 1.2 & 1.0 & 2.3 & 0.9 \\
\hline Sweden & 1.9 & 1.5 & 1.9 & 1.9 & 1.8 \\
\hline United Kingdom & 1.9 & 2.5 & 1.9 & 2.1 & 1.8 \\
\hline United States & 2.1 & 2.1 & 2.1 & 2.0 & 2.2 \\
\hline
\end{tabular}

Sources: Duval and de la Maisonneuve (2010), OECD, Merola and Sutherland (2012), HSBC, United Nations Population Division and World Bank

A first exercise that allows for convergence is Ward (2011) in order to highlight the difference in growth prospects between developed and emerging economies due to this force and the different demographic projections. The authors use growth regressions to estimate the importance of convergence forces and then (in their preferred exercise) assume that laggards converge to leaders in terms of the usual variables of growth regressions.

Duval and Maisonneuve (2010) also allow for converge, but this time using a growth accounting framework. In particular, they allow countries to (slowly) converge to the top levels of education and physical capital while allowing some transition dynamics and heterogeneity in participation and unemployment rates. They also assume convergence in the TFP, but it does to the average growth rate of high TFP economies (which is 1.5 percent in their data).

As can be seen in the first and fourth columns of Table 5, these two exercises reduce the growth rate of the technological leader (and in some case that of the most advanced economies), while they give an extra kick to those economies that lag further behind in terms of education and physical capital, such as Ireland or Spain. 
OECD (2012) differentiates from Duval and Maisonneuve (2010) by allowing for more heterogeneity in participation and unemployment rates and by removing convergence in participation rates. At the same time, it lowers TFP growth of the leaders to 1.3 percent (see column two of Table 5). The results are, on average, more pessimistic than those of column two. And this is particularly the case for countries where participation rates today are well below best practices.

Finally, Merola and Sutherland (2012) just differ with us on allowing some dynamics on employment and participation rates until 2025, that is, they use the OECD Medium Term scenarios for employment and participation rates until 2025 and then assume they remain constant from that year onwards. For productivity they take the same scenarios until 2025, and after this date they assume convergence to the rate of the technological leader from 2025 to 2035. After 2035 productivity growth rates are assumed to remain constant at that level. As a consequence, their results do not differ that much from ours (see column three of Table 5), particularly in the period of comparison.

To sum up, the differences in results with our approach derive from the nature of our exercise. Our approach is more neutral than the ones described above. We avoid dealing with employment and participation rates given the elevated uncertainty around the future evolution of these variables due to the particularities of the current situation. Although, as the comparison with Merola and Sutherland (2012) shows, this does not seem to be a key issue since there are no major differences between their result and ours.

More importantly, we abstract from convergence issues since we do not believe these are going to be important. As we have argued above, most of the convergence in growth rates seems to have already happened. Moreover, modeling this requires taking a stand on the evolution of structural policies in the future for each country, and on the degree of convergence in stocks of factor endowments. And small differences in assumptions generate large differences in results, as shown by the comparison of columns four, one and two of Table 5 .

It is true that, in general, exercises that take into account some of these convergence ingredients present a more favourable perspective due to the convergence in levels of capital (human or physical) or by allowing for larger TFP growth of laggard economies. But this is not necessarily always the case, since this factor may add or reduce growth. An example of this is the case of Germany when comparing columns 1 (Duval and Maisonneuve, 2010) and 2 (OECD, 2012) of Table 5. And introducing convergence elements for advanced economies comes at the cost of making judgments which are not always easy to justify, adding subjectivity and speculation to the forecasts.

To sum up, our results, which are based purely on demographics and assume convergence in productivity per worker should be interpreted with care, but they have the attractive of being a simple approach, with low degree of subjectivity. Furthermore, they do not differ much from other more convoluted approaches. They show that, other things equal, working-age demographic projections in the coming decades will be a driving force for a general slowdown of GDP growth. And, in terms of productivity growth there are 200 years of evidence that suggest (when 
looking only at advanced economies that seem to have converged to the technological leader), that, very likely, things are going to stay equal.

It is also interesting to compare our results with a measure of potential output, defined as the level of output that an economy can produce at a constant inflation rate. ${ }^{10}$ We select the OECD measure, which uses the production function approach, and we compare our results with potential output in "real time" (that is, the estimation in year $t$ for potential output in the same year $t$ ) and the last series for potential output (covering also all previous years). Figure 5 contains this information for the U.S., United Kingdom, Japan, Spain, Germany and Italy, for the period 1996-2011.

Figure 5: Comparison between long-run GDP and OECD potential output (real-time and last revision)
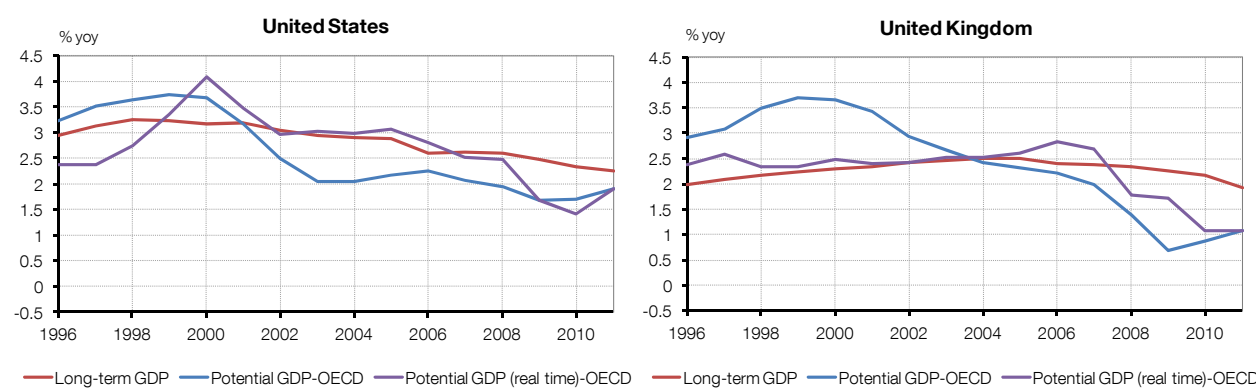

$$
\text { — Long-term GDP — Potential GDP-OECD — Potential GDP (real time)-OECD }
$$

Sources: United Nations Population Division (World Population Prospects: The 2010 Revision), World Bank and $\mathrm{OECD}$.

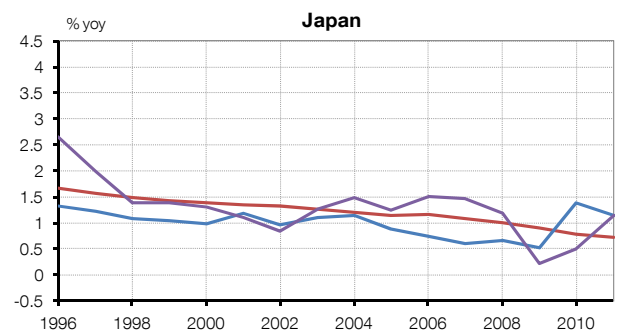
Sources: United Nations Population Division (World Population Prospects: The 2010
Revision), World Bank and OECD

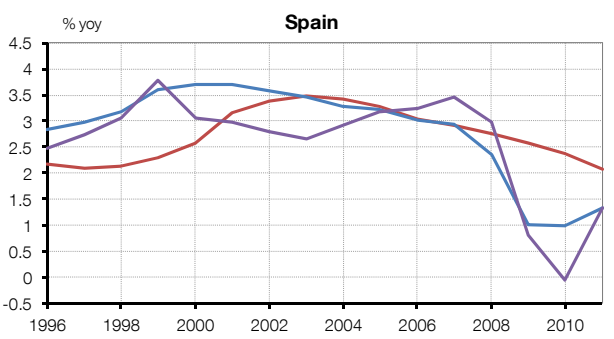

—Long-term GDP —Potential GDP-OECD —Potential GDP (real time)-OECD

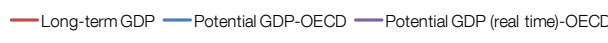
Sources: United Nations Population Division (World Population Prospects: The 2010
Revision). World Bank and OECD.

Sources: United Nations Population Division (World Population Prospects: The 2010
Revision). World Bank and OECD.
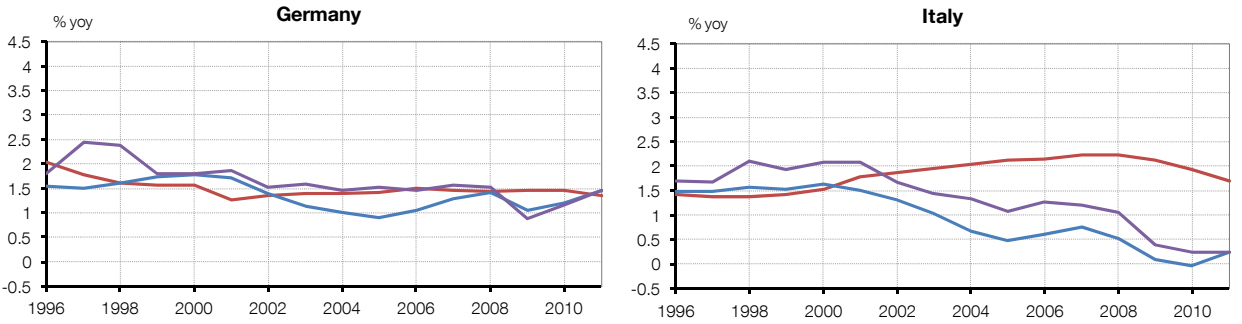

—Long-term GDP —Potential GDP-OECD —Potential GDP (real time)-OECD

Sources: United Nations Population Division (World Population Prospects: The 2010 Revision), World Bank and OECD.

— Long-term GDP —Potential GDP-OECD —Potential GDP (real time)-OECD

Sources: United Nations Population Division (World Population Prospects: The 2010

The first thing to note is how different the two OECD series are. This is consequence of the end-point problem of potential output estimate (see Baxter and King, 1995). Although this is a problem mainly of estimates that use filtering approaches, it also affects estimates of the potential output using the production function that use filter techniques in order to detrend the inputs of the production function.

10. This definition of potential output is not universal. It could, for instance, be also defined as the output in the case of no price stickiness in wages and prices. 
It is also interesting to note that the difference between both series is more remarkable in the case of countries that experienced a large boom during the expansion period, Spain, United Kingdom and the US. We could interpret the difference between the actual OECD series for potential output growth and the OECD real time series as the error in the estimation in real time. Then it could be argued that those errors were large, particularly in countries with large booms, and especially at the height of the boom.

On the other hand, if we compare these two measures with ours, our projections for long-run growth seem to behave more parsimoniously and tend to present an economic performance, during the expansion phase, which is in between the two OECD measures. That is, our measure of long term growth tracks more closely the final estimation of potential output growth when compared to the real time estimation.

Finally we compare our exercise with the most recent projections of potential output available. Figure 6 shows the forecast for GDP growth and potential GDP growth, both from the last issue of the World Economic Outlook of the IMF, and our measure of long-term growth.

Figure 6: Comparison between long-run GDP and IMF GDP forecasts of potential output (WEO)
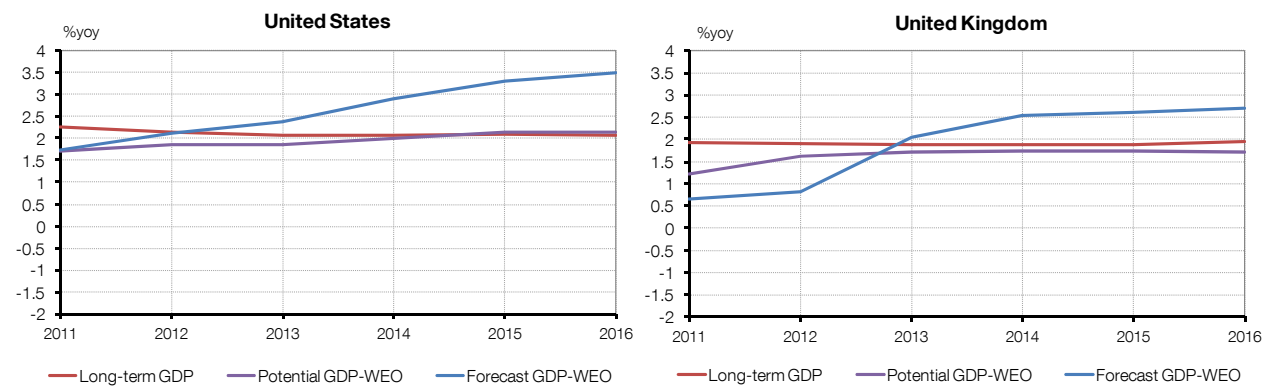

Sources: United Nations Population Division (World Population Prospects: The 2010 Revision), World Bank and IMF.

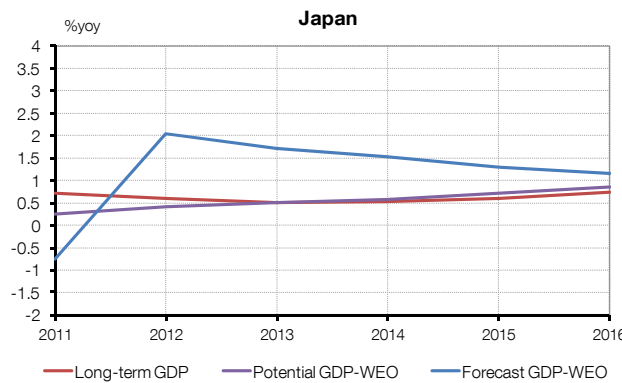

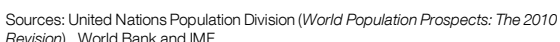

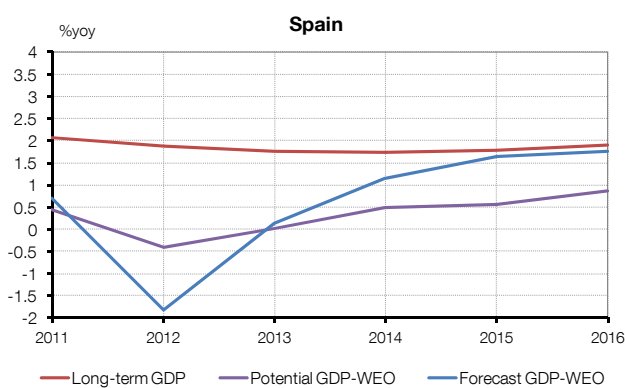

Sources: United Nations Population Division (World Population Prospects: The 2010 Revision), World Bank and IMF.

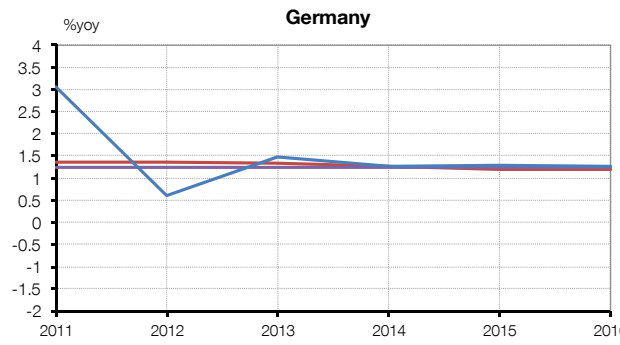

—Long-term GDP —Potential GDP-WEO —Forecast GDP-WEO

Sources: United Nations Population Division (World Population Prospects: The 2010 Revision, World Bank and IMF. Sources: United Nations Population Division (World Population Prospects: The 2010
Revision). World Bank and IMF.

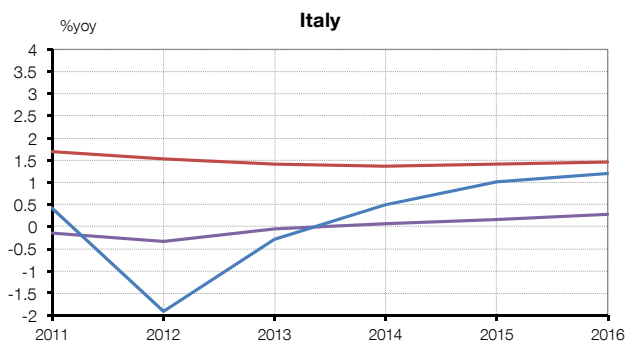

—Long-term GDP —Potential GDP-WEO —Forecast GDP-WEO

Sources: United Nations Population Division (World Population Prospects: The 2010 Revision), World Bank and IMF. 
The main message from this Figure is that for most countries (all but Spain and Italy) our measure of long term growth closely tracks the estimations of potential output growth of the IMF'11.

All the previous analyses reinforce the confidence in the robustness of our forecasts. They are both consistent with the past measures of potential output and with the projections of future GDP growth. 


\section{Conclusions}

This paper analyses the long-run growth rates of advanced economies. Growth rates are derived using only the growth in productivity (GDP per working-age person) and a demographic component. Productivity is assumed to grow in the long-run at a constant rate equal to that of the technology leader, an empirical regularity that, as we have argued, is very robust in the data. Our demographic projections come from widely used United Nations data.

Our results indicate a general deceleration of growth in advanced economies in the coming two decades, due to a slowdown in population growth. Despite this general message, there is substantial heterogeneity among advanced economies. In the case of Japan, Germany, Italy and Spain the prospects are more negative, since these countries face reductions in the size of their workforces that will significantly reduce their growth.

The immediate implication of this heterogeneity is that by 2050 the relative size of the GDP of these economies could change substantially, due to the heterogeneity of their demographic projections. In particular, France and the United Kingdom could have overtaken Germany to become the largest economies in Europe, while Spain will fall back in the ranking of nations in the sample, after its projected working-age population peaks in 2024.

This new phase of economic development represents a very significant challenge for policymakers. The immediate challenge in the current context is that, with large public debts in most developed economies, a slowdown in the growth rate, ceteris paribus, will make debt servicing more difficult by overburdening a stable or decreasing working-age population. And of course, this will have an effect on the sustainability of public pension systems. But the expected demographic evolution also has implications for other key variables, such as housing prices and aggregate demand. Although we do not explicitly explore these effects in this paper, it is important to highlight them in order to explain why the question that we pose is so important for the current design of public policies.

Finally, this paper has abstracted from emerging economies and convergence elements. Future work should include these elements, since taking into account the future evolution of developing economies may change the current map of economic dominance completely and, at the same time, that may help us to understand whether developed economies may obtain extra growth from these forces. We have discussed some exercises that try to do this, but we have argued that it comes at the cost of adding uncertainty, and that small differences in assumptions generate large differences in results. 


\section{References}

AGHION, P. and P. HOWITT (1992), A Model of Growth through Creative Destruction, Econometrica, 60(2), 323-351.

BAXTER, M. and KING, R.G. (1995). "Measuring business cycles: approximate band-pass filters for economic series", NBER Working paper, No.5022.

DUVAL, R. and DE LA MAISONNEUVE, C. (2010). "Long-Run Growth Scenarios for the World Economy", Journal of Policy Modeling, Elsevier, Vol. 32(1).

HOWITT, P. (2000). Endogenous growth and cross-country income differences. American Economic Review 90(4), 829-846 .

HOWITT, P. and MAYER-FOULKES, D. (2005). R\&D, implementation, and stagnation: A Schumpeterian theory of convergence clubs. Journal of Money, Credit and Banking 37(1), 147-77.

INTERNATIONAL MONETARY FUND (IMF) (2012). World Economic Outlook - April 2012 dataset, [Online], Available: http://www.imf.org/external/pubs/ft/weo/2012/01/weodata/index.aspx [26 Apr 2012].

MADDISON, A. Historical Statistics of the World Economy: 1-2008 AD, [Online], Available:

www.ggdc.net/maddison/Historical Statistics/horizontal-file 02-2010.xls [20 Dec 2011].

MEROLA, R. and SUTHERLAND, D. (2012). "Fiscal Consolidation: Part 3. Long-Run Projections and Fiscal Gap Calculations", OECD Economics Department Working Papers, No. 934.

ORGANISATION FOR ECONOMIC CO-OPERATION AND DEVELOPMENT (OECD), Economic Outlook No. 60-90, [Online], Available: http://stats.oecd.org/Index.aspx [20 Dec 2011].

ORGANISATION FOR ECONOMIC CO-OPERATION AND DEVELOPMENT (OECD), Economics Department (2012). Long-term growth scenarios, OECD Publications, p. 73.

ROMER, P. M. (1990). Endogenous technological change. Journal of Political Economy 98(5), 71-102.

SOLOW, ROBERT M. (1956), A Contribution to the Theory of Economic Growth, Quarterly Journal of Economics, 70 , 65-94.

THE WORLD BANK (2012). Catalog Sources World Development Indicators, [Online], Available: http://data.worldbank.org/ [15 Dec 2011].

UNITED NATIONS, DEPARTMENT OF ECONOMIC AND SOCIAL AFFAIRS, POPULATION DIVISION (2011a). World Population Prospects: The 2010 Revision, [Online], Available: http://esa.un.org/unpd/wpp/Excel-Data/population.htm [15 Dec 2011].

UNITED NATIONS, DEPARTMENT OF ECONOMIC AND SOCIAL AFFAIRS, POPULATION DIVISION (UNPD), (2011b). World Population Prospects: The 2010 Revision, Volume l: Comprehensive Tables, UNPD Publications, pp. 27-38. WARD, K. (2011). "The world in 2050: Quantifying the shift in the global economy", HSBC Global Research. Global Economics, January 2011, p. 22. 


\section{BANCO DE ESPAÑA PUBLICATIONS}

\section{OCCASIONAL PAPERS}

0501 JOSÉ RAMÓN MARTÍNEZ-RESANO: Size and heterogeneity matter. A microstructure-based analysis of regulation of secondary markets for government bonds.

0502 ALICIA GARCÍA-HERRERO, SERGIO GAVILÁ and DANIEL SANTABÁRBARA: China's banking reform: an assessment of its evolution and possible impact.

0503 ANA BUISÁN, DAVID LEARMONTH and MARÍA SEBASTIÁ BARRIEL: An industry approach to understanding export performance: stylised facts and empirical estimation.

0504 ANA BUISÁN and FERNANDO RESTOY: Cross-country macroeconometric heterogeneity in EMU.

0505 JOSÉ LUIS MALO DE MOLINA: Una larga fase de expansión de la economía española.

0506 VÍCTOR GARCÍA-VAQUERO and JORGE MARTÍNEZ: Fiscalidad de la vivienda en España.

0507 JAIME CARUANA: Monetary policy, financial stability and asset prices.

0601 JUAN F. JIMENO, JUAN A. ROJAS and SERGIO PUENTE: Modelling the impact of aging on Social Security expenditures.

0602 PABLO MARTÍN-ACEÑA: La Banque de France, la BRI et la création du Service des Études de la Banque d’Espagne au début des années 1930. (There is a Spanish version of this edition with the same number).

0603 CRISTINA BARCELÓ: Imputation of the 2002 wave of the Spanish Survey of Household Finances (EFF).

0604 RAFAEL GÓMEZ and PABLO HERNÁNDEZ DE COS: The importance of being mature: The effect of demographic maturation on global per-capita income.

0605 JUAN RUIZ and JOSEP VILARRUBIA: International recycling of petrodollars. (There is a Spanish version of this edition with the same number).

0606 ALICIA GARCÍA-HERRERO and SERGIO GAVILÁ: Posible impacto de Basilea II en los países emergentes.

0607 ESTHER GORDO, JAVIER JAREÑO and ALBERTO URTASUN: Radiografía del sector de servicios en España.

0608 JUAN AYUSO, ROBERTO BLANCO and FERNANDO RESTOY: House prices and real interest rates in Spain.

0701 JOSÉ LUIS MALO DE MOLINA: Los principales rasgos y experiencias de la integración de la economía española en la UEM.

0702 ISABEL ARGIMÓN, FRANCISCO DE CASTRO and ÁNGEL LUIS GÓMEZ: Una simulación de los efectos de la reforma del IRPF sobre la carga impositiva.

0703 YENER ALTUNBAȘ, ALPER KARA and ADRIAN VAN RIXTEL: Corporate governance and corporate ownership: The investment behaviour of Japanese institutional investors.

0704 ARTURO MACÍAS and ÁLVARO NASH: Efectos de valoración en la posición de inversión internacional de España.

0705 JUAN ÁNGEL GARCÍA and ADRIAN VAN RIXTEL: Inflation-linked bonds from a central bank perspective.

0706 JAVIER JAREÑO: Las encuestas de opinión en el análisis coyuntural de la economía española.

0801 MARÍA J. NIETO and GARRY J. SCHINASI: EU framework for safeguarding financial stability: Towards an analytical benchmark for assessing its effectiveness.

0802 SILVIA IRANZO: Delving into country risk. (There is a Spanish version of this edition with the same number).

0803 OLYMPIA BOVER: The Spanish survey of household finances (EFF): Description and methods of the 2005 wave.

0804 JAVIER DÍAZ-CASSOU, AITOR ERCE-DOMÍNGUEZ and JUAN J. VÁZQUEZ-ZAMORA: Recent episodes of sovereign debt restructurings. A case-study approach.

0805 JAVIER DÍAZ-CASSOU, AITOR ERCE-DOMÍNGUEZ and JUAN J. VÁZQUEZ-ZAMORA: The role of the IMF in recent sovereign debt restructurings: Implications for the policy of lending into arrears

0806 MIGUEL DE LAS CASAS and XAVIER SERRA: Simplification of IMF lending. Why not just one flexible credit facility?

0807 MIGUEL GARCÍA-POSADA and JOSEP M. ${ }^{a}$ VILARRUBIA: Mapa de exposición internacional de la economía española.

0808 SARAI CRIADO and ADRIAN VAN RIXTEL: Structured finance and the financial turmoil of 2007-2008: An introductory overview. (There is a Spanish version of this edition with the same number).

0809 FRANCISCO DE CASTRO and JOSÉ M. GONZÁLEZ-MÍNGUEZ: La composición de las finanzas públicas y el crecimiento a largo plazo: Un enfoque macroeconómico.

0810 OLYMPIA BOVER: The dynamics of household income and wealth: results from the panel of the Spanish survey of household finances (EFF) 2002-2005. (There is a Spanish version of this edition with the same number).

0901 ÁNGEL ESTRADA, JUAN F. JIMENO and JOSÉ LUIS MALO DE MOLINA: The Spanish economy in EMU: the first ten years. (There is a Spanish version of this edition with the same number).

0902 ÁNGEL ESTRADA and PABLO HERNÁNDEZ DE COS: Oil prices and their effect on potential output. (There is a Spanish version of this edition with the same number). 
0903 PALOMA LÓPEZ-GARCÍA, SERGIO PUENTE and ÁNGEL LUIS GÓMEZ: Employment generation by small firms in Spain.

0904 LUIS J. ÁLVAREZ, SAMUEL HURTADO, ISABEL SÁNCHEZ and CARLOS THOMAS: The impact of oil price changes on Spanish and euro area consumer price inflation.

0905 CORAL GARCIA, ESTHER GORDO, JAIME MARTÍNEZ-MARTÍN and PATRY TELLO: Una actualización de las funciones de exportación e imporción de la economía española.

1001 L. J. ÁlVAREZ, G. BULLIGAN, A. CABRERO, L FERRARA and H. STAHL: Housing cycles in the major euro area countries.

1002 SONSOLES GALLEGO, SÁNDOR GARDÓ, REINER MARTIN, LUIS MOLINA and JOSÉ MARÍA SERENA: The impact of the global economic and financial crisis on Central Eastern and SouthEastern Europe (CESEE) and Latin America

1101 LUIS ORGAZ, LUIS MOLINA and CARMEN CARRASCO: El creciente peso de las economías emergentes en la economía y gobernanza mundiales. Los países BRIC

1102 KLAUS SCHMIDT-HEBBEL: Central banking in Latin America: changes, achievements, challenges. (There is a Spanish version of this edition with the same number).

1103 OLYMPIA BOVER: The Spanish Survey of Household Finances (EFF): description and methods of the 2008 wave.

1104 PABLO HERNÁNDEZ DE COS, MARIO IZQUIERDO and ALBERTO URTASUN: An estimate of the potential growth of the Spanish economy. (There is a Spanish version of this edition with the same number).

1105 ENRIQUE ALBEROLA, CARLOS TRUCHARTE and JUAN LUIS VEGA: Central banks and macroprudentia policy. Some reflections from the Spanish experience. I

1106 SAMUEL HURTADO, ELENA FERNÁNDEZ, EVA ORTEGA and ALBERTO URTASUN: Nueva actualización del modelo trimestral del Banco de España.

1107 PABLO HERNÁNDEZ DE COS and ENRIQUE MORAL-BENITO: Health care expenditure in the OECD countries: efficiency and regulation. (There is a Spanish version of this edition with the same number).

1201 ELOÍSA ORTEGA and JUAN PEÑALOSA: The Spanish economic crisis: key factors and growth challenges in the euro area. (There is a Spanish version of this edition with the same number).

1202 MARÍA J. NIETO: What role, if any, can market discipline play in supporting macroprudential policy?

1203 CONCHA ARTOLA and ENRIQUE GALÁN: Tracking the future on the web: construction of leading indicators using internet searches. (There is a Spanish version of this edition with the same number).

1204 JOSÉ LUIS MALO DE MOLINA: Luis Ángel Rojo en el Banco de España.

1205 PABLO HERNÁNDEZ DE COS Y CARLOS THOMAS: El impacto de la consolidación fiscal sobre el crecimiento económico. Una ilustración para la economía española a partir de un modelo de equilibrio general.

1206 GALO NUÑO, CRISTINA PULIDO and RUBÉN SEGURA-CAYUELA: Long-run growth and demographic prospects in advanced economies.

\begin{tabular}{r|c|}
\hline BANCODEESPAÑ & Unidad de Servicios Auxiliares \\
Alcalá, 48 - 28014 Madrid \\
Eurosistema & $\begin{array}{c}\text { Telephone +34 91 } 3386360 \text {. Fax +34 } 913386488 \\
\text { E-mail: publicaciones@bde.es } \\
\text { www.bde.es }\end{array}$ \\
\hline
\end{tabular}

